\title{
МЕТОД КОМПЕНСАЦИИ АКТИВНОЙ СОСТАВЛЯЮЩЕЙ КОМБИНИРОВАННОЙ ПОМЕХИ В КОГЕРЕНТНО-ИМПУЛЬСНОЙ РЛС
}

\author{
ПИЗА Д. М., ЗВЯГИНЦЕВ Е. А., МОРОЗ Г. В.
}

Запорожский национальный технический университет, Украина, Запорожье, 69063, ул. Жуковского, 64

\begin{abstract}
Аннотация. Исследовано совместное воздействие активной и пассивной помехи на когерентно-импульсную радиолокационную станцию. Разработана математическая модель, реализующая новый метод компенсации активной составляющей комбинированной помехи в когерентно-импульсной РЛС, использующий спектральные отличия в структуре активных и пассивных помех. В результате моделирования установлено, что при поляризационно-временной обработке сигналов, использование режекторных фильтров для подавления пассивных помех в цепях формирования весовых коэффициентов автокомпенсатора позволяет существенно повысить качество компенсации активной помехи в условиях воздействия комбинированных помех. Показано, что режекция пассивной помехи в цепях формирования весовых коэффициентов исключает искажение спектра пассивной помехи на выходе адаптивного поляризационного фильтра
\end{abstract}

Ключевые слова: когерентно-импульсный радар; автокомпенсатор; комбинированная помеха; поляризационно-временная обработка; искажение спектра; помехозащищенность

\section{ВВЕДЕНИЕ}

Известно, что компенсация активных шумовых помех (АШП) может быть обеспечена путем использования гетеродинных [1] или квадратурных [2] автокомпенсаторов помех, а также при использовании адаптивных антенных решеток [3]. В первом случае основным и компенсационным каналами радиолокатора принимаются полезные сигналы и помехи. Затем путем регулирования весовых коэффициентов за счет использования корреляционной обратной связи компенсируются АШП, действующие как по главному лучу диаграммы направленности антенны, так и по боковым лепесткам [4].

Однако при комбинированном воздействии активных помех и переотражений от пассивных отражателей пространственно-распределенный характер последних разрушает про- странственную корреляцию сигналов точечных активных излучений [5]. Это приводит к снижению компенсации активной составляющей комбинированной помехи. На участках дальности в угловых направлениях, где пассивная составляющая комбинированной помехи является преобладающей, компенсация АШП может оказаться вообще проблематичной. При этом также разрушается временная корреляция отражений от пассивных помех, что усложняет выделение полезных сигналов на их фоне. Последнее объясняется модуляцией пассивной составляющей комбинированной помехи весовыми коэффициентами автокомпенсатора помех. Для эффективной компенсации активных помех необходимо сформировать классифицированную обучающую выборку, порожденную только активной составляющей комбинированной помехи. 